The Digital Object Identifier - DOI: 10.37952/ROI-jbc-01/19-59-9-106

Submitted on September 10, 2019.

\title{
The impact of oxidative stress on the neurotoxic effect of acetaminophen
}

\author{
(C) Yulia A. Vlasova, ${ }^{1,2 *}$ Ksenia A. Zagorodnikova, ${ }^{1}$ \\ Irina S. Ivanova, ${ }^{2}$ and Alexander S. Chukhno ${ }^{2,3+}$ \\ ${ }^{1}$ Central Research laboratory. North-Western State Medical University Named after I.I. Mechnikov. \\ Piskarevsky Ave., 47, Pav.4. St. Petersburg, 195067. Russia. \\ Phone: +7 543-05-22. E-mail: k.zagorodnikova@szgmu.ru \\ ${ }^{2}$ North-Western State Medical University Named after I. I. Mechnikov. Piskarevsky Ave., 47, Pav.5. \\ St. Petersburg, 195067. Russia. Phone: +7 303-50-00 (add. 8213). E-mail: k.zagorodnikova@szgmu.ru \\ ${ }^{3}$ Department of Physical and Colloid Chemistry. St. Petersburg State Chemical-Pharmaceutical University. \\ Professor Popov St., 14. St. Petersburg, 197376. Russia. Phone: +7 (812) 499-39-00 (4140). \\ E-mail:alex-chuhno@yandex.ru
}

*Supervising author; ${ }^{+}$Corresponding author

Keywords: acetaminophen, oxidative stress, neurotoxic effect, PC12 line.

\section{Abstract}

Paracetamol (acetaminophen, APAP) is a commonly-used antipyretic and analgesic. However, there have been reports indicating possible link between its use in pregnancy and impaired neuropsychic development in children. A number of prospective studies of the possible negative effect of acetaminophen on the development of a child after his mother took this drug during pregnancy, as well as the results of studies on glioma cells and neurons in murine cortex, may indicate presence of the neurotoxic effect of acetaminophen. It is currently unclear if paracetamol itself being pharmacologically active neurotropic substance, or its metabolites, one of which - NAPQI ( $N$-acetyl-p-benzoquinone imine) known by its toxic effects in mitochindria, play the most significant role in proposed neurotoxicity. Therefore it seems important to study each metabolite separately.

The ability of acetaminophen(paracetamol) in concentrations of $1 \mathrm{mg} / \mathrm{ml}$ and $2 \mathrm{mg} / \mathrm{ml}$ to reduce cell viability was shown on cells of the PC12 neuronal line using MTT-method, which is based on the ability of mitochondria of viable cells to restore formazan 3-(4,5-dimethylthiazole)-2,5-diphenyl-2tetrazolium bromide (MTT). Concentrations of $0.125 \mathrm{mg} / \mathrm{ml}, 0.25 \mathrm{mg} / \mathrm{ml}$ and $0.5 \mathrm{mg} / \mathrm{ml} \mathrm{had} \mathrm{no} \mathrm{similar}$ impact on cell culture viability. In addition, the impact of hydrogen peroxide (as an inducer of oxidative stress) on the neurotoxic effect of acetaminophen was studied. We demonstrated that in the presence of $0.3 \mathrm{mM}$ or $0.5 \mathrm{mM}$ hydrogen peroxide and acetaminophen in concentrations of $1 \mathrm{mg} / \mathrm{ml}$ and $2 \mathrm{mg} / \mathrm{ml}$ reliably reduced the percentage of surviving cells. We showed that the decrease of the viability of the cells of the PC12 neuronal line is obvious only after exposure to high concentrations of acetaminophen, especially in the presence of hydrogen peroxide, which means that neurotoxic effect is not likely to occur in vivo.

\section{References}

[1] K.G. Becker, S.T. Schultz. Similarities in features of autism and asthma and a possible link to acetaminophen use. Med Hypotheses. 2010. Vol.74. P.7-11.

[2] M. Mohanem, M. Hazem, A. Ashraf. Effects of Paracetamol and Monosodium Glutamate on Cerebellar Granule Cells of the Adult Male Albino Rats: A His.and Morph. Study Med. J. Cairo Univ. 2014. Vol.82. No.2. P.289-302.

[3] H. Viberg, P. Eriksson, T. Gordh, A. Fredriksson. Paracetamol (Acetaminophen) Administration During Neonatal Brain Development Affects Cognitive Function and Alters Its Analgesic and Anxiolytic Response in Adult Male Mice. Tox. Sci. 2014. Vol.138. No.1. P.139-147.

[4] C. Avella-Garcia, J. Julvez, J. Fortuny, C. Rebordosa, R. García-Esteban, I. Galán, A. Tardón, L. Rodríguez-Bernal, C. Iñiguez, A. Andiarena, L. Santa-Marina, J. Sunyer. Acetaminophen use in 
pregnancy and neurodevelopment: attention function and autism spectrum symptoms. Int.J.of Epidemiology. 2016. Vol.45. No.6. P.1987-1996.

[5] Z. Liew, B. Ritz, J. Virk, J. Olsen. Maternal use of acetaminophen during pregnancy and risk of autism spectrum disorders in childhood: A Danish national birth cohort study. Autism Res. 2016. Vol.9. No.9. P.917-1016.

[6] V. Aleksandrova, N.V. Senyavina, D.V. Maltseva, A.A. Khutornenko, and D.A. Sakharov p53- and Caspase-3-Independent Mechanism of Acetaminophen Effect on Human Neural Cells. Bull.of Exp. Biol. and Med. 2016. Vol.160. No.6. P.763-766.

[7] I.O. Zakharova, T.V. Sokolova, Y.A. Vlasova, V.V. Furaev, M.P. Rychkova, N.F. Avrova. GM1 ganglioside activates ERK1/2 and Akt downstream of Trk Tyrosine Kinase and protect PC12 cells against Hydrogen Peroxide toxicity. Neurochemical Research. 2014. Vol.39. No.11. P.2262-227.

[8] N.F. Avrova, T.V. Sokolova, I.O. Zakharova, V.V. Furaev, M.P. Rychkova, Yu.A. Vlasova. Neuroprotective and metabolic effects of micro- and nanomolar concentrations of ganglioside GM1 on PC12 cells under oxidative stress. Neurochemistry. 2008. Vol.25. No.1. P.90-98. (russian)

[9] S. Schultz, M. DeSilva, T. Gu, M. Qiang, K. Whang. Effects of the Analgesic Acetaminophen (Paracetamol) and its para-Aminophenol Metabolite on Viability of Mouse-Cultured Cortical Neurons. Basic \& Clinical Pharmacology \& Toxicology. 2011. Vol.110. P.141-144.

[10] C. Ghanem, M. Pérez, J. Manautou, A. Mottino. Acetaminophen; from liver to brain: new insights into drug pharmacological action and toxicity. Pharmacol Res. 2016. Vol.109. P.119-131. 